\title{
Insect resistance management in Bacillus thuringiensis cotton by MGPS (multiple genes pyramiding and silencing)
}

\author{
ZAFAR Muhammad Mubashar ${ }^{1}$, RAZZAQ Abdul ${ }^{1}$, FAROOQ Muhammad Awais ${ }^{2}$, REHMAN Abdul ${ }^{1,2,3}$, \\ FIRDOUS Hina ${ }^{4}$, SHAKEEL Amir ${ }^{2}$, MO Huijuan ${ }^{1,3^{*}}$ and REN Maozhi ${ }^{1,3^{*}}$
}

\begin{abstract}
The introduction of Bacillus thuringiensis (Bt) cotton has reduced the burden of pests without harming the environment and human health. However, the efficacy of Bt cotton has decreased due to field-evolved resistance in insect pests over time. In this review, we have discussed various factors that facilitate the evolution of resistance in cotton pests. Currently, different strategies like pyramided cotton expressing two or more distinct Bt toxin genes, refuge strategy, releasing of sterile insects, and gene silencing by RNAi are being used to control insect pests. Pyramided cotton has shown resistance against different cotton pests. The multiple genes pyramiding and silencing (MGPS) approach has been proposed for the management of cotton pests. The genome information of cotton pests is necessary for the development of MGPS-based cotton. The expression cassettes against various essential genes involved in defense, detoxification, digestion, and development of cotton pests will successfully obtain favorable agronomic characters for crop protection and production. The MGPS involves the construction of transformable artificial chromosomes, that can express multiple distinct Bt toxins and RNAi to knockdown various essential target genes to control pests. The evolution of resistance in cotton pests will be delayed or blocked by the synergistic action of high dose of Bt toxins and RNAi as well as compliance of refuge requirement.
\end{abstract}

Keywords: Bt cotton, RNAi, Multiple genes pyramiding and silencing (MGPS), Bt resistance

\section{Introduction}

Cotton (Gossypium hirsutum) is an ultimate source of fiber for the textile industry and seed oil for biofuel. China, India, USA, Pakistan, Brazil and Australia are the leading cotton producers (Figs. 1 and 2). The G. hirsutum and G. barbadense account for $90 \%$ and $8 \%$ of the global cotton production, respectively. Globally, 150 countries are involved in cotton industrial chain, providing income for more than 100 million families and employment for almost $7 \%$ of all labor in developing countries (Fig. 3). The global cotton production in 2018-2019 is 118.5 million bales which is $4.2 \%$ lower than the previous year (Dohlman et al. 2019). The insect

\footnotetext{
* Correspondence: mohuijuan86@163.com; renmaozhi01@caas.cn ${ }^{1}$ Institute of Cotton Research, Chinese Academy of Agricultural Sciences, Anyang 455000, Henan, China

Full list of author information is available at the end of the article
}

pests and diseases cause 15\% 30\% economic losses to cotton production and even up to $50 \%$ losses by direct damage or transmission of plant diseases (Cui et al. 2007; Chen et al. 2020; Tarazi et al. 2019). The major insect pests which cause substantial losses to cotton production are cotton jassid, cotton aphid, thrips, spotted bollworm, pink bollworm, American bollworm, cotton mealy bug, pink boll worm, fall armyworm and whitefly. The excessive use of pesticides leads to the insecticidal resistance, pest resurgence that exacerbates the situation. These chemicals kill indiscriminately beneficial and harmful insects, and also deteriorate the environment and human health (Sanahuja et al. 2011).

In the mid-1990s, the Monsanto (US company) developed Bacillus thuringiensis (Bt) cotton and then commercialized it to different cotton producing countries. The transgenic cotton kills some voracious insect pests without harming

(c) The Author(s). 2020 Open Access This article is licensed under a Creative Commons Attribution 4.0 International License, which permits use, sharing, adaptation, distribution and reproduction in any medium or format, as long as you give appropriate credit to the original author(s) and the source, provide a link to the Creative Commons licence, and indicate if changes were made. The images or other third party material in this article are included in the article's Creative Commons licence, unless indicated otherwise in a credit line to the material. If material is not included in the article's Creative Commons licence and your intended use is not permitted by statutory regulation or exceeds the permitted use, you will need to obtain permission directly from the copyright holder. To view a copy of this licence, visit http://creativecommons.org/licenses/by/4.0/. 


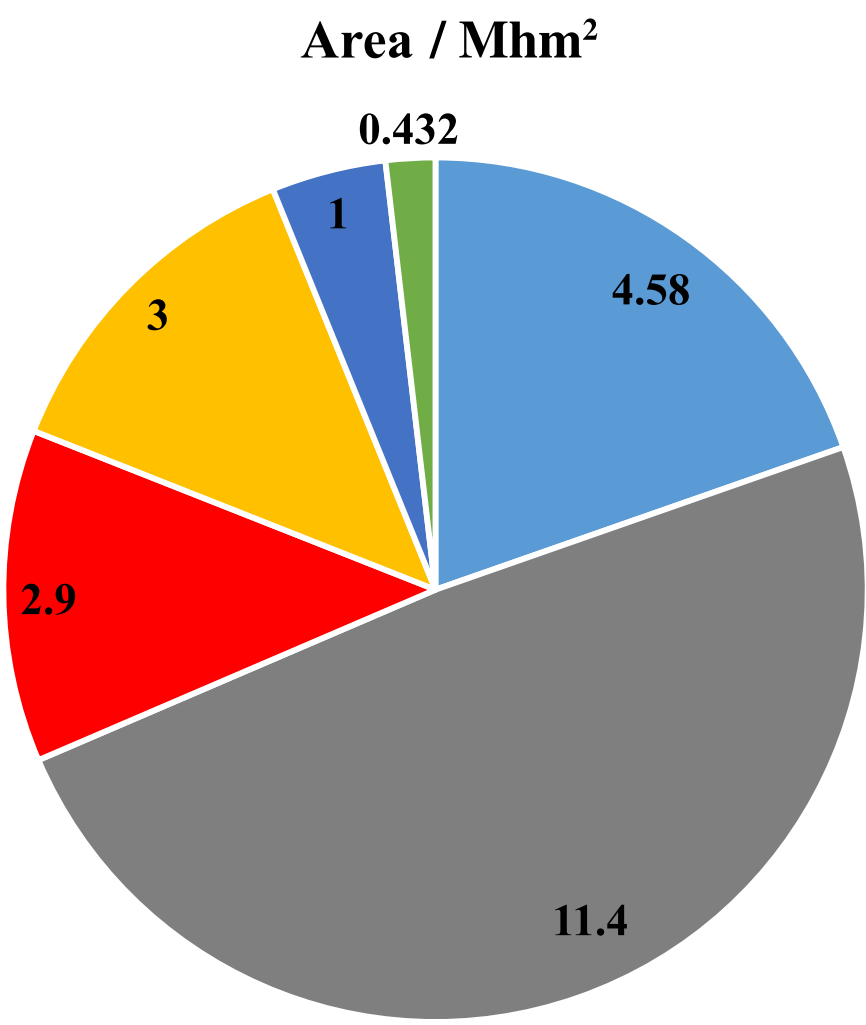

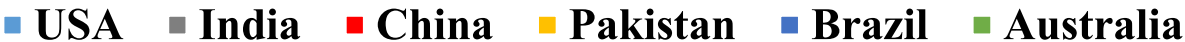

Fig. 1 Bt cotton planted area (million hectares) in major cotton producing countries (ISAAA 2018)

environment as well as human health and increases the yield and farmers' profit by reducing the application of insecticides (Flachs 2017; Wu et al. 2008). In eight cotton producing countries, the adoption of genetic modified (GM) insect resistant (IR) cotton causes reduction of over 331 million $\mathrm{kg}$ of insecticide active ingredient. The transgenic cotton is highly selective, efficient for numerous key lepidopteran pests, ecofriendly, and become an important part of intergrated pest management (IPM) (Naranjo 2011).

Globally, the transgenic cotton is grown on area of more than 33 million hectares (Tarazi et al. 2019). The adoption of Bt cotton has reduced the application of insecticides up to 305 million kilogram in China, India and USA during the period of 1996-2018. It has also minimized the farmers' exposure to hazardous insecticides, increased the yield and profits, and suppressed the insect pests population of cotton (Brookes and Barfoot 2020a, b). Globally, the adoption of transgenic cotton has grown up to $42 \%$ from 2017 to 2018 and its adoption by major cotton growing countries was remarkable, such as China (95\%), India (93\%), USA (96\%), Brazil (84\%) and Australia (100\%) (ISAAA 2018). In India, Bt cotton has increased the yield by $100 \%$ (Kranthi and Stone 2020). The adoption of transgenic cotton in India has reduced the pest damage, increased $24 \%$ yield per acre and
$50 \%$ profits (Fleming et al. 2018). In China, the Bt cotton has reduced the insecticide applications (47\% to $79 \%)$ (Veettil et al. 2017).

The Bt crops provide significant economic and environmental advantages but these benefits can be eliminated by the evolution of resistance in insects and pests (Carpenter 2010; Tabashnik et al. 2013; Tabashnik et al. 2010). The growing of Bt crops on a large scale exerts more selection pressure on insect pests and results in resistance against insecticidal activity of Bt crops. The 21 cases of field-evolved resistance have been reported that decrease the efficacy of nine Cry proteins (Tabashnik and Carrière 2020; Calles-Torrez et al. 2019). To date, seven targeted pests of Bt crops have control problem due to the development of resistance (Tabashnik and Carrière 2017; Tabashnik et al. 2013). The efficacy of Bt crops has decreased due to field-evolved resistance. The field-evolved resistance is genetically controlled and reduced the susceptibility to Bt toxin caused by exposure of a pest population to the toxin in the field (Tabashnik et al. 2009). The proteins Cry1Ac belonged to Cry1A family is most widely used in Bt cotton to control some lepidopteran larvae. The open field resistance in Pectinophora gossypiella to $C r y 1 A c$ and $C r y 1 A b$ is reported in 


\section{Production $/ 10^{3}$ metric tons}

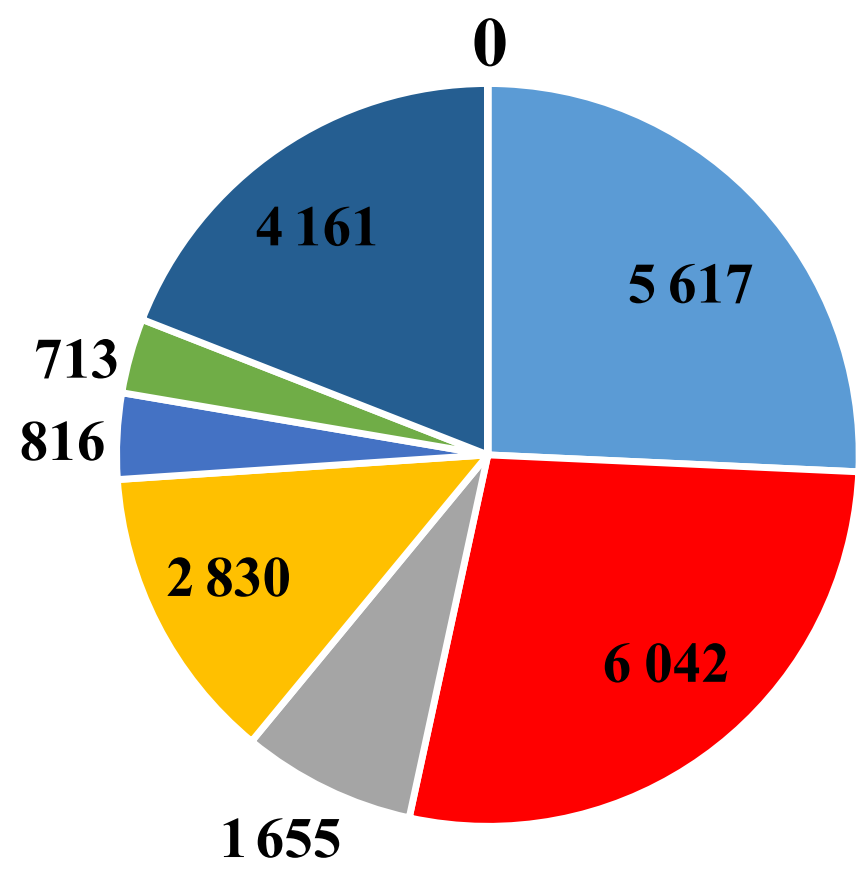

\section{India $\quad$ China $\quad$ Pakistan $\quad$ Brazil \\ - Turkey Uzbekistan $\square$ Other}

Fig. 2 Cotton production by country worldwide in 2018/2019 (1 000 metric tons) (USDA 2019)

India (Naik et al. 2020). In USA, the Helicoverpa zea showed resistance to transgenic cotton exhibiting Cry1Ac and $C r y 2 A b$ (Tabashnik et al. 2013). The analysis of 51 field-obtained strains of $P$. gossypiella exhibits significant lower susceptibility to Cry1Ac during 2008 to 2010 than 2005 to 2007, that validated the evolution of resistance in pink bollworm (Wan et al. 2012). The evolution of resistance to Cry1Ac of $H$. armigera in open field condition (Tabashnik et al. 2013) has served as a warning because it has also gained the resistance against Bollgard-I cotton since 2012 (Tabashnik and Carrière 2017; Cui et al. 2007). Four cases of field-evolved resistance to transgenic crops expressing single toxin of $\mathrm{Cry} 1 \mathrm{~A}$ class are confirmed (Bemisia fusca, Cry $1 A b$ maize, $H$. zea, Cry1Ac cotton, Spodoptera frugiperda, Cry1F maize, H. armigera, Cry1Ac cotton) (Tabashnik et al. 2009). Worldwide, the practical resistance against different endotoxins in seven major insect species has been reported (Naik et al. 2018; Tabashnik et al. 2013; Grimi et al. 2015). The third generation of transgenic technology is promising and is being tested in the fields against different insects and pests attacks. For example, different constructs containing Cry $1 A c, C r y 2 A, V i P 3 A$ and EPSPS have been synthesized and developed. The $3^{\text {rd }}$ generation Bt cotton exhibits three genes $(C r y 1 A c+C r y 2 A b+V i p 3 A)$, $(C r y 1 A b+C r y 2 A c+$ Vip3Aa19 $)$ or $\quad(C r y 1 A c+C r y 1 F+$ Vip $3 A)$. In Australia, the $3^{\text {rd }}$ generation cotton expressing Cry1Ac + Cry $2 A b+\operatorname{Vip} 3 A a$ was planted on more than $90 \%$ area during 2016-2017 (Tabashnik and Carrière 2017). In case of USA, the $3^{\text {rd }}$ generation cotton expressing Cry and Vip3Aa covered $27 \%$ area of total cotton growing area in 2019 (USDA-FAS 2019). Most of the cotton pests like corn earworm, bollworms and fall armyworms get resistance to pyramided cotton expressing Cry $1 A c+C r y 1 F$ and $C r y 1 A c+$ $C r y 2 A b$ and other combinations of different Cry genes (Reisig et al. 2018; Tabashnik and Carrière 2017). Various studies have confirmed the development of field-evolved resistance in major cotton pests against different Cry proteins used in the $3^{\text {rd }}$ generation Bt cotton, but only Vip3A is consistently effective against these pests (Tabashnik and Carrière 2017). The efficacy of Vip3A protein used in pyramided crops will be reduced due to resistance 


\section{Income benefits / million US \$}

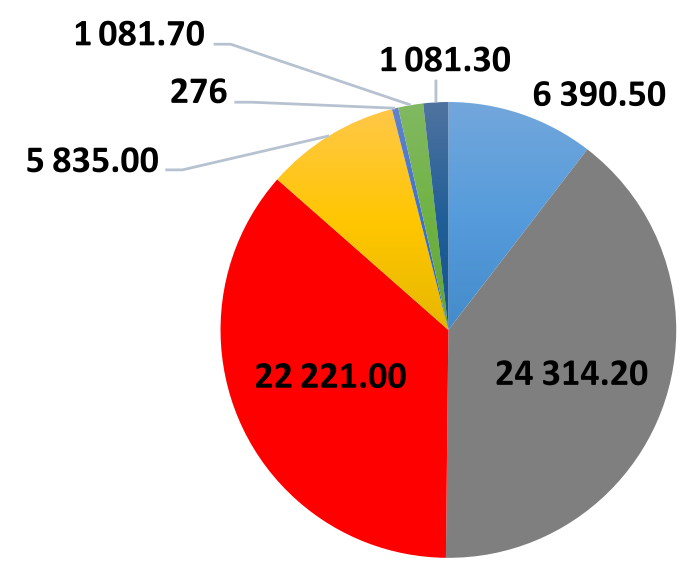

USA India China Pakistan Brazil Australia Argentina

Fig. 3 Income benefits of genetic modified (GM) cotton farm in selected countries, 1996-2016 (million US\$) (Brookes and Barfoot 2020a, b)

development in pests against Cry proteins (Reisig et al. 2018). Reisig et al. (2018) also reported the increased damage to fruiting structure of pyramided cotton expressing two or multiple Bt genes by Cry1Ac resistant population of $H$. Zea. In another study, the population of $H$. Zea which have decreased susceptibility to $C r y 1 A c$, showed increased survival \& damage to Bollgard II and Bollgard III cotton (Little et al. 2019). The results of this study suggested that the addition of Vip3Aa gene in the $3^{\text {rd }}$ generation cotton is not sufficient for the management of pests which are resistant to Cry proteins. To preserve the efficacy of Vip3Aa proteins in pyramided cotton, the application of other resistance management tactics are necessary (Little et al. 2019). Yang et al. (2019) reported early warning of resistance in $H$. Zea against Vip3A protein. The cotton leaf bioassay of $H$. Zea larvae obtained from pyramided maize expressing Cry $1 A b+C r y 1 F+V i p 3 A$ showed well survival on WideStrike3 cotton expressing Cry1Ac + Cry1F + Vip3A proteins (Yang et al. 2019). In another study, statistical significant, weak cross resistance is confirmed between Vip3 and Cry1 toxins with a mean of 1.5 -fold cross-resistance in 21 cases (range: 0.30 4.6-fold) (Tabashnik and Carrière 2020). Six cases of resistance in different insects against Vip3A have been reported, including S. litura (Barkhade and Thakare 2010), S. frugiperda (Bernardi et al. 2016; Yang et al. 2018), H. armigera (Chakroun et al. 2016), H. Zea (Little et al. 2019) and H. virescens (Pickett et al. 2017).

\section{Factors contributing to resistance in insect pests of cotton}

In Lepidopteran larvae, ATP-binding cassette (ABC) transporters, alkaline phosphatases (ALP), membrane bound cadherin (CAD) in midgut, and aminopeptidase
N (APN) play a vital role in insecticidal activity. Gene expression modulation and mutations in receptor sites of insects are major reasons for Bt resistance decrease. The modification in Bt receptors, reduction of proteolytic activity in midgut and regeneration or replacement in midgut cell are responsible factors for resistance development to $\mathrm{Bt}$ toxins. The mutations disrupting a cadherin protein are tightly linked with recessive resistance to Cry1Ac in $H$. armigera, P. gossypiella and H. virescens (Gahan et al. 2001; Morin et al. 2003; Xu et al. 2005; Li et al. 2019). In field derived populations of $H$. armigera, recessive cadherin alleles accounted for $75 \%$ to $84 \%$ of resistance alleles detected. However, major resistance alleles were found in heterozygotes whereas at least one non-recessive resistance allele was observed in 59\% 94\% of resistant individuals (Zhang et al. 2012). The cadherin allele $r_{1}$ and other cadherin resistance alleles accounted for $88 \%$ of the resistance alleles in field derived population of cotton bollworm (Zhang et al. 2012). The cellular trafficking is affected by CAD transmembrane mutation, causing resistance in $P$. gossypiella to Cry1Ac Bt toxin (Wang et al. 2018b). The mutations in promotor of trypsin gene (HaTryR) induced Cry1Ac resistance in $H$. armigera (Liu et al. 2014). The resistance to Cry1Ac in cotton bollworm occurred due to different mechanisms like qualitative changes or reduced levels of the confirmed and putative midgut receptors cadherin, alkaline phosphatase, aminopeptidase, and $\mathrm{ABCC} 2$ proteins (Zhang et al. 2012; Zhang et al. 2009; Jurat-Fuentes et al. 2011; Xiao et al. 2014). Three altered alleles of the cadherin encoding gene associated with $\mathrm{Cry} 1 \mathrm{Ac}$ resistance in 
pink bollworm were deletion (Morin et al. 2003). Mutations in $\mathrm{ABC}$ transporter proteins cause resistance to Cry 1 and Cry2 toxins in eight Lepidopteran species (Heckel 2012; Wu et al 2019). The mutation in an ABC transporter gene $(P g A B C A 2)$ is linked with resistance to $C r y 2 A b$ in pink bollworm (Mathew et al. 2018). The missplicing of $A B C C 2$ gene results in loss of 150 amino acids and causes resistance in $H$. armigera to Cry $1 A c$. The mutation in $A B C A 2$ gene conferred resistance to $C r y 2 A b$ in $H$. armigera. The CRISPR/Cas9 mediated downregulation of $H a A B C A 2$ results in resistance to Cry2Aa and Cry $2 A b$ in cotton bollworm (Wang et al. 2020). Various ABC transporters bind to different $\mathrm{Bt}$ toxins; for example, $A B C C 2$ is a receptor for $C r y 1 A b$ and $C r y 1 A c$, and $A B C A 2$ for $C r y 2 A b$ (Tay et al. 2015). The proteomic and genomic studies showed reduced expression of ALP in Bt resistant strains of $H$. armigera, $H$. virescens, and $S$. frugiperda than that in susceptible (Jurat-Fuentes et al. 2011). In $H$. armigera, a deletion mutation in the HaAPN1 gene is linked with the resistance to Cry1Ac (Zhang et al. 2009).

The concentration of toxin in Bt plants should be high enough to kill all or nearly all hybrid progeny, which is called "high dose" criterion. In India and China, the bollworm developed resistance to Cry genes because Bt cotton has not met the criterion of high dose. The field data of approved Bt cotton varieties expressing Cry1Ac from these countries showed significant survival of susceptible $P$. gossypiella larvae (Wan et al. 2004; Bambawale et al. 2010), indicating the non-fulfillment of the high dose criterion. In India, pink bollworm got resistance to Bt cotton after 7 years due to the use of illegal $B t$ cotton seeds with low doses of Bt protein and non-compliance with the refuge strategy (Huang et al. 2011). The S. frugiperda and $H$. zea became resistant to Cry1Ac due to lower dose in Bt corn and cotton (Ali et al. 2006; Storer et al. 2012). Low expression level helps operate the natural selection in increasing the frequency of mutated resistant population.

Different studies suggested that the growing refuges with $\mathrm{Bt}$ crop reduced the selection pressure in susceptible insect pests of cotton and delayed the evolution of resistance. Lack of refuge caused high selection pressure which resulted in resistance in insect pests of cotton. The resistance in S. frugiperda (Storer et al. 2012) and $P$. gossypiella (Tabashnik et al. 2012) occurred owing to scarcity of refuges. The growing of non-Bt plants with Bt plants allowed the survival of susceptible individuals in Bt dominated environment. The random mating between dominant susceptible (SS) and recessive resistant (RR) individuals resulted in heterozygous (RS) progeny, which could be killed by Bt crops. The fulfilment of high dose criteria lessened the process of rapid resistance development, and in some instances, if this standard was not maintained throughout the growing season, the resistance could be delayed for more than 10 years with abundant refuges (Tabashnik et al. 2013).

From different geographical studies, it is evident that several other factors could also contribute to resistance development in pests against Bt cotton. These factors include lack of regulation and compliance withenvironment protection agency (EPA), multiple exposure to same Bt endotoxins, cross resistance to multiple $\mathrm{Bt}$ endotoxins and failure of producing high Bt endotoxin dose (Huang et al. 2011). For instance, $C r y 1 A b$ and $C r y 1 A c$ are still being practiced even after 20 years of its incorporation in most varieties of Bt cotton and corn, and a cross resistance in $H$. $z e a$ was detected between these two endotoxins (Brevault et al. 2013; Crespo et al. 2015). The simultaneous cultivation of a pyramid with a mono-toxin plants expressing a toxin, which is also part of pyramid toxins, can accelerate evolution of resistance to the pyramid. The resistance strain of S. frugiperda to Cry $1 F a$ get rapid resistance to pyramid of corn producing Cry1A.105 $+C r y 2 A b$, because the toxins $\mathrm{Cry} 1 \mathrm{Fa}$ and Cry $1 \mathrm{~A} .105$ are closely related (Santos-Amaya et al. 2015; Tabashnik et al. 2013).

Different studies suggested that the insecticidal efficacy of Bt cotton varied owing to variable expression of Bt protein during the cotton growing season (Chen et al. 2017a; Wan et al. 2005). The factors affecting the Bt concentration in transgenic cotton are discussed in Table 1.

The variance of insect resistance in cotton bollworm and armyworm is linked with differential expression of Cry $1 A c$ in field, that effected by environment, varietal background as well as the age of plant (Chen et al. 2017a; Chen et al. 2018). Bt protein expression could be regulated by promotor, nucleotide sequence, insertion point, transgene amplification, natural conditions and cell's environmental factors (Wang et al. 2018c; Downes et al. 2016; Hobbs et al. 1993). Overwhelmingly, insecticidal ability was directly or indirectly influenced by intensity of pest and diseases, rain fall, soil characteristics and adequate and appropriate farm management. Taking all together, optimal environment is necessary for GM cotton production which ultimately leads to reinforce the expression of Bt gene.

\section{Genome information of major insect pests of cotton}

The host-plant diversification involves the expansion of chemosensory gene families used for recognition of volatile and nonvolatile molecules (Gouin et al. 2017). Chemical signals are detected by proteins which comprised of multigene families and moderately in size. These families encompasses: (i) ionotropic receptors (IR), (ii) chemoreceptor super family consisting of gustatory receptors (GRs) and olfactory receptors (OR), (iii) chemosensory proteins (CSPs) and odorant binding proteins (OBPs) (Sánchez-Gracia et al. 2001). The GRs are present on taste sensilla on tarsi, mouthparts and 
Table 1 Factors reducing the Bt concentration in cotton

\begin{tabular}{|c|c|c|}
\hline Factors & Effects & References \\
\hline Salinity & $\begin{array}{l}\text { Significantly decrease the concentration of Bt protein in cotton leaves and insecticidal } \\
\text { activity against cotton bollworm hampered with enhancement of soil salinity ( } 11.46 \mathrm{dS} \text {. } \\
\left.\mathrm{m}^{-1}\right) \text {. As for as soil salinity increases } 9.1 \mathrm{dS} \cdot \mathrm{m}^{-1} \text {, significant reduction of insecticidal protein } \\
\text { in squares was observed. }\end{array}$ & Wang et al. 2018 \\
\hline Waterlogging & $\begin{array}{l}\text { The Bt protein content greatly decreased in squares by waterlogging. It reduced the } \\
\text { Bt protein content frome } 38 \% \text { to } 50 \% \text { in leaves from the } 1^{\text {st }} \text { to the } 3^{\text {rd }} \text { week under stress. }\end{array}$ & Luo et al. 2008 \\
\hline Drought & $\begin{array}{l}\text { In water deficit stress the content of Bt protein in boll shells and associated insect } \\
\text { resistance decreased. In moderate water-deficit conditions Bt concentrations decreased } \\
\text { in leaves, flowers and bolls. }\end{array}$ & Zhang et al. 2017 \\
\hline Humidity & High humidity reduced the Bt toxins in leaf of cotton. & Yuan et al. 2012 \\
\hline Temperature & $\begin{array}{l}31-35^{\circ} \mathrm{C} \text { is the best range for maximum expression Cry } 1 \text { Ac toxin in transgenic cotton. } \\
\left.\text { High temperature reduced the leaf }\left(37^{\circ} \mathrm{C}\right) \text { and square (above } 38^{\circ} \mathrm{C}\right) \text { protein content, and } \\
\text { notable reduction of insecticidal protein in boll shell was observed at } 38^{\circ} \mathrm{C} \text { after } 24 \mathrm{~h} \text {. }\end{array}$ & $\begin{array}{l}\text { Rana et al. 2015, } \\
\text { Zhang et al. } 2018\end{array}$ \\
\hline Genotype & Expression of Bt insecticidal protein varies among different genotypes of cotton. & $\begin{array}{l}\text { Adamczyk and Sumerford 2001; } \\
\text { Bakhsh et al. 2012; Khan et al. 2018b }\end{array}$ \\
\hline Plant age & $\begin{array}{l}\text { In Bt cotton, content of insecticidal protein varies with the age of plant, and after } 110 \\
\text { days of planting, level of toxins falls below the threshold level. }\end{array}$ & Dong and Li 2007, Kranthi et al. 2009 \\
\hline Plant parts & Cry1Ac expression was the highest in leaves, followed by squares, bolls and flowers. & Chen et al. 2017a, Chen et al. 2018 \\
\hline $\begin{array}{l}\text { Agronomic } \\
\text { practices }\end{array}$ & $\begin{array}{l}\text { Insect resistance and Bt expression were enhanced by nitrogen fertilizer. } 14 \% \text { increase of } \\
\text { Bt toxins in leaf was observed by high nitrogen fertilizer whereas plant growth regulators } \\
\text { enhance the Bt toxins in squares. }\end{array}$ & Chen et al. 2018, Chen et al. 2017a \\
\hline
\end{tabular}

ovipositors where they recognize non-volatile molecules (e.g. bitter compounds salts and sugar) present on food substances and oviposition substrates (Isono and Morita 2010). OBPs and CSPs proteins exist on lymph antennae and dendrites of olfactory receptor neurons (ORNs). The OBPs and CSPs can catch and bind environmental chemical cues and then conveyed to ORs or IRs (Xu et al. 2009). The ORs are important especially for insect and host odor recognition (Carey et al. 2010). IRs are involved in detecting environmental chemical signals. Different antennal IRs perform various functions in the process of insects' recognition of external information (Chen et al. 2015). The evolution of resistance to insecticide occurs by interaction of multiple genes.

The increased metabolic detoxification and reduced target site sensitivity are major outcomes of insecticide resistance. In insects, the host toxic secondary metabolites and xenobiotics are normally detoxified by UDPglycosyltransferases, esterases (CCES), glutathione-stransferases (GSTs) and cytochrome P450s (CYPs) (Gouin et al. 2017). Despite the various sizes of CYPomes in insects, many genes, often of CYP 3 and CYP 4 clans, are arrayed in tight clustersof tandemly duplicated genes, reflecting recent duplications. The presence of multiple, closely related CYP genes in the genomes of insect pests presents a challenge to the functional identification of the genes that are important in adaptation to plant chemicals and detoxification of insecticides (Wang et al. 2018a). Insecticide resistance is outcome of duplication of genes encoding detoxification enzymes (Bass et al. 2013). The GSTs are involved in various biological activities including xenobiotic detoxification and secondary metabolism (SylvestreGonon et al. 2019). Esterases are entangled in neurogenesis, hormone and pheromone degradation, developmental regulation and xenobiotics detoxification. The UGTs played a vital role in endobiotic regulation and xenobiotics detoxification by catalyzing sugar with small hydrophobic compounds to produce glycosides (Teese et al. 2010). In herbivorous insects, the metabolism is governed by essential digestive proteases. The serine proteases (SPs) and serine protease homologs (SPHs) are involved in numerous physiological processes like digestion, development and immunity (Yang et al. 2017b).

In $S$. frugiperda the higher number of GRs $(N=231$ genes), OBPs (50 genes), CSP repertoire (22 genes), OR (69 genes), and IR (42 genes) were found. Expansion occurs in GRs and OBPs, because tandem duplications and strong conservation in candidate antennal IRs were found (Gouin et al. 2017). The variety of evolutionary adaptive characteristics is a result of gene duplication (Conant and Wolfe 2008). A total of 117 CYP genes were annotated in $S$. frugiperda and strong gene expansion was observed in CYP6, CYP9, CYP321, CYP324 and CYP4 families. The S. frugiperda have 46 GST genes. These GST genes exhibit extraordinary diversification of epsilon class and expansion of epsilon and delta cytosolic classes. Its genome contained 96 carboxyl/cholinesterases (CCEs) with notable expansions. The expansion through tandem duplications is found in UGTs gene families which also revealed patterns of interspecific 
conservation in gene number. The S. frugiperda has conservative antioxidant defense system. There are $86 \mathrm{di}-$ gestive $S P$ genes and rapid gene duplication was found (Gouin et al. 2017). Chemosensory genes were found, showing almost non-significant variation in both $\mathrm{C}$ and $\mathrm{R}$ strains but significant variation in gene number of detoxification and digestion genes. The difference of detoxification and digestion genes between both strains results in differential adaptation to various ranges of hostplant (Gouin et al. 2017).

The whitefly Bemisia tabaci (Gennadius) is a phloem feeding insect, recognized as a complex composed of 35 morphocryptic species. Within the species complex, the highly invasive and destructive species are Middle EastAsia Minor 1 (MEAM1/B) and Mediterranean (MED/Q) (Xie et al. 2018). Across the hemipteran insect genomes, $B$. tabaci has low genome synteny. The MEAM1/B and MED/Q are intricate in detoxification and metabolism reflecting similar gene families (Xie et al. 2018). The genome of MEAM1/B has 130 P450 genes, 81 UGT genes, 22 GST genes, $50 \mathrm{ABC}$ genes and $51 \mathrm{COE}$ genes. However, the MED/Q genome has $153 \mathrm{P} 450$ genes, 63 UGT genes, 21 GST genes, $59 \mathrm{ABC}$ genes and $51 \mathrm{COE}$ genes. The MEAM1/B and MED/Q have significant expansion in P450 detoxification gene family, and CYP3 and CYP4 clades of MED/Q were expanded largely. This remarkable expansion in metabolic and detoxification genes results in insecticide resistance in $B$. tabaci (Xie et al. 2018). The significant expansion of cytochrome P450s, UDP-glucuronosyltransferases cathepsins, and phosphatidylethanolamine-binding proteins were found in genome of MEAM1/B (Chen et al. 2016). Eight $O B P$ and 19 CSP genes were identified in MEAM1/B. The phylogenetic analyses revealed lineage-specific expansion in CSP genes (BtabBCSP1, BtabBCSP3, BtabBCSP13, BtabBCSP17, BtabBCSP18 and BtabBCSP19) (Zeng et al. 2019). The global invasion of pests and their resistance to resistance is a result of expansion of genes involved in chemo sensation, metabolism, detoxification and those related to pesticide resistance, as well as virus acquisition (Chen et al. 2016).

There are 12 OBPs, 23 IRs, 34 ORs and 50 GRs, all belong to chemosensory related genes, in genome of Aphis gossypii Glover. There are 62 P450s, 72 ABCs, 7 GSTs, 20 CCEs and 56 UGTs (all belong to detoxification related genes) in A. gossypii. As compared with other aphids, the A. gossypii has lower IRs, OR and GR (Quan et al. 2019). It is suggested that the size of chemosensory genes is closely associated with the host range in aphids (Nicholson et al. 2015). The A. gossypii genome also encodes extra $\mathrm{ABC}$ genes and fewer GSTs than other aphid species (Quan et al. 2019).

Pink bollworm is also regarded as model insect to understand the insect responses to $\mathrm{Bt}$ toxins. The molecular bases of its tolerance are not well documented. The 46458 transcripts derived from 39874 unigenes were used to construct a transcriptome assembly for the midgut of $P$. gossypiella.

The transcriptome data presented midgut proteins which are important for detoxification of xenobiotic, digestion of nutrients and their allocation, as well as for the discovery of protein receptors crucial for Bt intoxication (Tassone et al. 2016).

Final assembly of $H$. armigera contains 997 scaffolds with a total genome size of $337 \mathrm{Mb}$. The scaffold N50 size was $1.00 \mathrm{Mb}$. H. armigera detoxification gene families consist of 114 P450s, 97 CCEs, 42 GSTs, and 46 UGTs and 54 ABCs. The chemosensory gene families involved 84 ORs, 213 GRs, 29 CSP and 40 OBPs. The serine proteases, major digestive clades, consist of 45 trypsins and 49 chymotrypsins genes. Across the 300 genes, $H$. armigera detoxification gene families had over 70 genes, i.e., GSTs, CCEs and P450s, whereas over 90 gene families corresponding with digestion and more than 150 are chemosensory genes. The polyphagy behavior and insecticide resistance in $H$. armigera is due to extensive amplification, duplication and neofunctionalisation of genes involved in detoxification, chemosensation and digestion (Pearce et al. 2017).

The lack of detailed genome study on P. solenopsis is a barrier to understand the molecular bases of its growth, development as well as insecticide resistance. The RNASeq technology was applied to execute de novo transcriptome assembly and comparative transcriptome profiling of different developmental phases of P. solenopsis. About 182.67 million reads were assembled into 93781 unigenes with an average length of $871.4 \mathrm{bp}$ and an N50 length of $1899 \mathrm{bp}$. The differentially expressed gene (DEG) libraries exhibited 29415 DEGs upon comparison of gene expression profiles among different developmental stages. DEGs were associated with hormone biosynthesis, developmental processes, anti-microbial protection and functional protein synthesis. This study provides genomics resource covering all developmental stages of $P$. solenopsis and helps to identify vital RNAi target to control it (Arya et al. 2018). In P. solenopsis, present molecular sequence resources were amplified through de novo transcriptome assembly, and RNA sequencing generated 12925 coding sequence (CDS) from 23643 contigs with an average size of $1077.5 \mathrm{bp}$ per CDS. At all developmental stages, the expression of targeted genes (AQP, IAP,CAL, VATPase, SNF7, $\alpha$-amylase, chitin synthase and bursicon) was studied and the silencing of these genes by injecting their respective dsRNA was achieved (Singh et al. 2019b). Fourteen candidate reference genes were assessed at five various stages as well as under starvation stress. The results revealed that GST, Actin, TFIID, SDHA, and 28s were identified as 
the several best reference genes for expression analysis studies in mealybug (Singh et al. 2019a).

\section{Management strategies Gene pyramiding}

The pyramided crops producing two or more distinct $\mathrm{Bt}$ toxins belongs to Cry or Vip insecticidal proteins are designed to impede the resistance evolution. In early 2000s, the pyramided Bt cotton was introduced for resistance management and control of insect pests like bollworm of cotton. Now in USA, Australia, India, and China, single Bt gene cotton has been replaced with pyramided Bt cotton that produces two Bt toxins, either Cry $1 A c$ and Cry1F or Cry $1 A c$ and Cry2Ab (Brevault et al. 2013). In 2004, the single Bt gene $(C r y 1 A c)$ is replaced by pyramided cotton expressing $\mathrm{Cry} 1 \mathrm{Ac}+$ $\mathrm{Cry} 2 \mathrm{Ab}$ in Australia for the management of $\mathrm{H}$. punctigera and $H$. armigera (Downes and Mahon 2012). The development of resistance has been delayed for more than a decade after the introduction of this pyramid. The co-expression of Vip3A \& Cry1Ac enhanced the insecticidal activity of transgenic cotton against lepidopteran pests. The pyramiding of vip $3 A c A a$ and cry $1 A c$ genes into cotton has increased the larval mortality rates of S. litura, A. ipsilon and S. exigua as compared with single Bt-Cry1Ac cotton (Chen et al. 2017b). In S. frugiperda (Cry1F resistant), cross-resistant was observed against Cry1Ac and Cry1Ab. However, it was not crossresistant to Vip3A, Cry2Ae and Cry2Ab2. Because of this cross-resistance mechanism among Cryl proteins, the pyramided cotton expressing two or more Bt genes to control Cry1F-resistant S. frugiperda has become necessary (Yang et al. 2017a). The recessive resistance was found in Cry1F-resistant S. frugiperda. The pyramiding of different $\mathrm{Bt}$ genes in corn was effective for managing the Cry $1 F$ resistance in S. frugiperda (Niu et al. 2014).

\section{Factors effecting the durability of pyramids}

Durability of pyramids crops is enhanced by following conditions: i) refuges are abundant; ii) frequency of resistance alleles is rare; iii) resistance is recessive; iv) fitness costs are linked with resistance; v) resistance is not complete; vi) the multiple toxins in pyramid can kill all susceptible pests; vii) there is no cross resistance among toxins used in pyramid; viii) there is no simultaneous cultivation of pyramids with mono-toxin plants that exhibits one of the toxins used in the pyramid. Retrospective analysis of all cases showed that significant deviations from the first three conditions causes practical resistance to single toxin crops (Brevault et al. 2013; Carrière et al. 2015; Zhao et al. 2005).

The cross-resistance has reduced the efficacy of pyramids, and it happens when selection of a pest population with one Bt toxin causes genetically controlled reduction in sensitivity to other toxins (Tabashnik et al. 2014). Theoretically, weak or strong cross-resistance will speed up resistance development in insect pests which are genetically less susceptible to Bt crops, while only strong crossresistance will speed up resistance in pests which are inherently more susceptible to Bt crops (Carrière et al. 2015). The cross resistance occurs in those Bt toxins which have more similar amino acid sequence and share more similar binding sites in midgut of insect. The similarity of the amino acid sequence in domain II of Bt toxins is associated with cross resistance between toxins in the pyramids. A recent assessment of cross resistance in 10 important pests against seven sets of Bt toxin in 80 cases verified this pattern and revealed that the resemblance of amino acid sequence of domain II is linked with crossresistance (Carrière et al. 2015). So, pyramiding of two or more toxins which are not cross resisted by the target pest is a better strategy for resistance management. It is supposed that the resistance to Bt toxins is autosomal and governed by single diallelic recessive genes. Redundant killing of pests is decreased by strong cross resistance among toxins, because if the target pest is resistant to one toxin of the pyramid, then it can survive to other toxins (Tabashnik et al. 2014). The stronger cross-resistance is likely to occur in Cry1, Cry2 and Cry3 toxins because they are more similar and share similar three-domain structure. If the pests have weak cross-resistance but more inherently susceptible to Bt toxins, the resistance development to pyramids will be accelerated. But if the pests have less inherent susceptibility with weak cross resistance, the evolution of resistance to Bt toxins of the pyramid can be accelerated (Carrière et al. 2015). The weaker cross resistance was observed among Cry3Bb or $m C r y 3 A a \& C r y 34 / 35 A b$ because of different structural homology (Gassmann et al. 2014). The simultaneous cultivation of a pyramid with a monotoxin plants that express a toxin which is also part of pyramid toxins can accelerate evolution of resistance to the pyramid. The resistance strain of $S$. frugiperda to Cry1Fa get rapid resistance to dual gene $\mathrm{Bt}$ corn producing Cry1A.105 and Cry2Ab because the toxin Cry1Fa is closely related to Cry1A.105 toxin (Santos-Amaya et al. 2015). The cross-resistance and antagonism among toxins used in pyramids are common. The similarity of amino acid sequence in domains II and III is the major cause of cross-resistance and antagonism (Carrière et al. 2015).

\section{High dose/refuge strategy}

Transgenic crops can only be deemed successful if they have high dose/refuge strategy, which means that: 1) the Bt crops must express high dose; 2) the frequency of resistance alleles should be low; 3) abundant refuges (non Bt plants) are grown with Bt crops. The fieldevolved resistance in fall armyworm and pink bollworm 
is well documented in many countries. The factors which are involved in the field-evolved resistance of the insects against Bt-cotton are failure of the crop to express high dosage and lack of sufficient refuge plants (Huang et al. 2011). The concentration of each toxin in the pyramid must be high enough to kill $95 \%$ of the insect's susceptible populations. The pyramid will be more effective, if each toxin in a pyramid acts independently and kills $99.75 \%$ of susceptible pests (Carrière et al. 2015). Among 18 observations of nine test-pyramid combinations, only half met this criteria (Carrière et al. 2015). In case of pyramid cotton that expressed Cry1Ac and $C r y 2 A b$, the mortality rate of $H$. zea and H. armigera was more than $99.75 \%$ (Carrière et al. 2015).

The refuge strategy plays an important role in regulating the evolution of resistance to Bt crops. The approach mainly depends on mating between resistant and susceptible individuals produced in $\mathrm{Bt}$ and non-Bt (refuge) host plants. The random mating between dominant susceptible (SS) and recessive resistant (RR) individuals results in heterozygous (RS) progeny, that can be killed by Bt crops (Tabashnik and Carrière 2017) so that the resistance against insects can be delayed against Btcrops (Jin et al. 2015; Carriere et al. 2012; Tabashnik et al. 2008). The susceptible insects live and grow on refuges (non-Bt plants). This is an effective way that can lead to the delay in the development of resistance in pests against Bt-crops that can assist in using the same genes for the longer period of time (Carrière et al. 2016).

\section{Other strategies}

To delay resistance, releasing sterile insects (Tabashnik et al. 2010) and seeds mixture strategy (Carrière et al. 2016) are also used. The development of modified Bt toxins is also used for the management of resistance. In this approach, the knowledge is involved inhow the insect pests acquire resistance against a toxin and then alter the formulating of that toxin so that resistance can occur in another manner that will lead to the delay in evolution of resistance to Bt-crops. Cry1AbMod and Cry1AcMod killed M. Sexta and P. gossypiella that had cadherin deletion mutations (Soberón et al. 2007). Modified toxins showed high insecticidal activity against the most resistant strains of $H$. virescens and $H$. armigera (Tabashnik et al. 2011). The conservation of natural enemies can be very effective in delaying the evolution of resistance in Bt-cotton. Nearly 500 species of natural enemies in cotton systems in China have been reported (Luo et al. 2014).

\section{RNAi}

RNA interference (RNAi) is a potential approach for effective insect control via downregulation of gene expression (Table 2). RNAi targets genomic sequences in the insect species to avoid those genomic regions that belong to the beneficial insects. The Bt-cotton gene pyramiding from $C r y 1 A c$ and $C r y 1 A b$ incorporates the resistance against bollworms coupled with RNAi, which assists in the dysfunctioning of those genes involved in the development of tolerance against Bt-genes, which results in long term resistance against bollworms in cotton $(\mathrm{Ni}$ et al. 2017). RNAi silencing involves the breakdown of dsRNA into short interfering RNA by the RNase II enzymes dicer and drosha, and these siRNA are loaded into another complex RNA-induced silencing complex (RISC). The siRNA is unwound during the RISC assembly and single stranded RNA hybridizes with mRNA target. Gene silencing results in two ways. The first is the nucleolytic degradation of the targeted mRNA by RNase enzyme Argonaute (Slicer), the second is that if there is mismatch between the mRNA and siRNA resultantly, mRNA cannot be cleaved, but resulting in a translational blockage. There are many RNAi methods, e.g., micro-injections, ds RNA spray and artificial diet-based feeding have been adopted. The efficacy of microinjection and feeding methods are variable depending on the type of genes and the organisms. Moreover, it has also been reported that neither of the two methods produce same results in the organisms (Watson 2018). These methods have been very successful in laboratory but they are not effective in the fields. At field level, in planta expression of dsRNAs to knockdown the specific genomic regions has been very economical for insect control (Younis et al. 2014). The dsRNA produced by transgenic plants against key gene of pests has been regarded as safeguard that endows transgenic resistant plants with new innovations (Mao et al. 2007) (Table 2). The main benefits of employing RNAi are its high degree of specificity and efficiency. Therefore, RNAi is used in the functional analysis of genes to evaluate the inhibition of genes that lead to the loss of any specific phenotypic functions (Majumdar et al. 2017).

\section{Multiple gene pyramiding and silencing}

Insect pests of cotton can acquire resistance against single Bt toxins; therefore, pyramided Bt cotton and efficacy of refuge for regulating the evolution of resistance against Bt-crops were introduced to overcome this resistance (Carrière et al. 2019). Recently, studies have suggested that insect pests (i.e., P. gossypiella, H. zea, S. frugiperda) have developed tolerance against dual gene pyramided cotton, and refuge also lost its efficacy in case of non-recessive resistance, i.e., cotton bollworm (Jin et al. 2015). Presently, new strategies are needed to be developed to delay the evolution of resistance in cotton pests. Plant-mediated RNAi of essential pest genes involved in defense, detoxification, digestion and development is being utilized for enhancing tolerance against insects and pests. In recent years, new types of insect resistant transgenic cotton have been developed using 
Table 2 Successful cases of plant mediated RNAi in different cotton pests

\begin{tabular}{|c|c|c|c|c|c|}
\hline $\begin{array}{l}\text { Insect } \\
\text { order }\end{array}$ & Target insect & Target genes & RNAi Plant & Effects of RNAi on the target insect & References \\
\hline \multirow[t]{7}{*}{ Lepidoptera } & H. armigera & $\begin{array}{l}\text { Cytochrome } 450 \\
\text { monooxygenase } \\
\text { CTP6AE14 }\end{array}$ & Cotton & $\begin{array}{l}\text { The larval growth and leaf consumption decreased } \\
61 \% \text { and } 39 \% \text {, respectively }\end{array}$ & Mao et al. 2011 \\
\hline & & $\begin{array}{l}\text { cytochrome P450 } \\
\text { CYP6AE14 }\end{array}$ & $\begin{array}{l}\text { A. thaliana, N. } \\
\text { tabacum, G. } \\
\text { hirsutum }\end{array}$ & $\begin{array}{l}\text { Retarded larval growth and the effects are more } \\
\text { dramatic in the presence of gossypol }\end{array}$ & Mao et al. 2007 \\
\hline & & $\begin{array}{l}\text { 3-hydroxy-3-methylglutaryl } \\
\text { coenzyme A reductase } \\
\text { (HMGR) }\end{array}$ & Cotton & Impairing the development and survival of larvae & Tian et al. 2015 \\
\hline & & HaHR3 & Cotton & $\begin{array}{l}\text { Higher larval mortality and deformities of pupation and } \\
\text { adult eclosion }\end{array}$ & Han et al. 2017 \\
\hline & & chitinase & Tobacco & $\begin{array}{l}\text { 0-33\% of larval mortality for various RNAi tobacco } \\
\text { lines }\end{array}$ & $\begin{array}{l}\text { Reddy and } \\
\text { Rajam } 2016\end{array}$ \\
\hline & & chitinase & Tomato & $\begin{array}{l}2 \%-45 \% \text { of larval mortality for various RNAi tomato } \\
\text { lines }\end{array}$ & $\begin{array}{l}\text { Reddy and } \\
\text { Rajam } 2016\end{array}$ \\
\hline & & JHAMT & Tomato & $\begin{array}{l}\text { Reduction in larval and pupal weight, abnormal } \\
\text { metamorphosis }\end{array}$ & $\begin{array}{l}\text { Maligeppagol } \\
\text { et al. } 2017\end{array}$ \\
\hline \multirow[t]{3}{*}{ Hemiptera } & Bemisia tabaci & v-ATPase & $\begin{array}{l}\text { Transgenic } \\
\text { lettuce }\end{array}$ & $\begin{array}{l}\text { 84\%-98\% mortality, 95-fold } \\
\text { lower fecundity }\end{array}$ & $\begin{array}{l}\text { Ibrahim et al. } \\
2017\end{array}$ \\
\hline & & $\begin{array}{l}\text { aquaporin and alpha } \\
\text { glucosidase }\end{array}$ & $\begin{array}{l}N . \\
\text { tabacum }\end{array}$ & $78 \%$ mortality & $\begin{array}{l}\text { Raza et al. } \\
2016\end{array}$ \\
\hline & & $\begin{array}{l}\text { acetylcholinesterase and } \\
\text { ecdysone receptor }\end{array}$ & $\begin{array}{l}\text { N. } \\
\text { tabacum }\end{array}$ & $90 \%$ mortality & $\begin{array}{l}\text { Malik et al. } \\
2016\end{array}$ \\
\hline Hemiptera & $\begin{array}{l}\text { Phenacoccus } \\
\text { solenopsis Tinsley }\end{array}$ & Bursicon and V-ATPase & N. tabacum & $\begin{array}{l}\text { Mortality, delayed development, deformed } \\
\text { individuals, with squeezed body and irregular } \\
\text { fragile cuticle }\end{array}$ & $\begin{array}{l}\text { Khan et al. } \\
\text { 2018a }\end{array}$ \\
\hline
\end{tabular}

RNAi technology or RNAi pyramided with Bt genes (Ni et al. 2017; Mao et al. 2011; Mao et al. 2013; Wu et al. 2016). Ni et al. (2017) developed a pyramid of cotton containing Bt and RNAi, and found excellent results against cotton bollworm, but also substantially delayed resistance as compare with using Bt alone.

Pyramiding of multiple RNAi expression cassettes against various essential genes involved in defense, detoxification, digestion and development of cotton pests will successfully obtain favorable agronomic characters for crop protection and production. The MGPS involves the construction of transformable synthetic chromosomes, that have multiple distinct Bt toxins and RNAi to knockdown various essential target genes of pest (Ren et al. 2019). The evolution of resistance in cotton pests will be delayed or blocked due to synergistic action of high dose of Bt toxins and RNAi(s) as well as compliance of ample refuge. The transgenic cotton based on MGPS coupled with refuge can be an effective and smart way to control pests.

\section{Conclusion}

The adoption of Bt cotton increase the yield, profit and reduced the application of pesticides as well as load of insect pests without harming the human health and environment. The development of resistance in insects and pests has reduced effectiveness of single and pyramided Bt cotton. The modification in midgut receptors, lack of high dose/refuge, cross resistance and fluctuation in expression of Bt protein during growing season are major factors that facilitate in resistance development. Besides, the resistance development in cotton pest and the drastic increment in population of secondary pest due to less application of insecticides have become a major concern for Bt cotton growers. Currently, different strategies like pyramided cotton expressing two or more distinct genes, refuge strategy, releasing of sterile insects, seed mixture, and genome editing by CRISPR/Cas9 and RNAi are being used to control insect pests. Recently, studies have suggested that insect pests (i.e., P. gossypiella, H. zea, S. frugiperda) have developed tolerance against dual gene pyramided cotton, and refuge also lost its efficacy in case of non-recessive resistance, i.e., cotton bollworm. The insects are remarkably adaptable and can develop resistance to any control tactics, including transgenic plants containing multiple Bt toxins and RNAi. The innovations like genetically modified Bt toxins and discovery of insecticidal proteins from bacteria other than $\mathrm{Bt}$ will continue to provide new tools for pest control. The MGPS-based cotton will be more durable with compliance of high refuges and other control tactics. 


\section{Authors' contributions}

Zafar MM and Razzaq A wrote the initial draft of the manuscript. Mo H, Farooq MA, Rehman $\mathrm{A}$ and Firdous $\mathrm{H}$ made all necessary corrections and carried out final editing of manuscript. Shakeel A and $\mathrm{Mo} \mathrm{H}$ proofread the manuscript. Final approval for publication was given by Ren M, the group leader at Institute of Cotton Research, CAAS. The author(s) read and approved the final manuscript.

\section{Funding}

This work was supported by the Genetically Modified Organisms Breeding Major Project of China (2019ZX08010004-004) and the National Natural Science Foundation of China (31901579).

\section{Availability of data and materials}

Not applicable.

\section{Ethics approval and consent to participate}

Not applicable.

\section{Consent for publication}

Not applicable.

\section{Competing interests}

Authors declare that they have no conflict of interest for the publication of the manuscript.

\section{Author details}

${ }^{1}$ Institute of Cotton Research, Chinese Academy of Agricultural Sciences, Anyang 455000, Henan, China. ${ }^{2}$ Department of Plant Breeding and Genetics, University of Agriculture Faisalabad, Faisalabad 38000, Pakistan. ${ }^{3}$ Zhengzhou Research Base, State Key Laboratory of Cotton Biology, Zhengzhou University, Zhengzhou 450000, China. ${ }^{4}$ Department of Plant Pathology, University of Agriculture Faisalabad, Faisalabad, Pakistan.

\section{Received: 16 June 2020 Accepted: 28 October 2020}

\section{Published online: 20 December 2020}

\section{References}

Adamczyk JJ, Sumerford DV. Potential factors impacting season-long expression of Cry1 Ac in 13 commercial varieties of Bollgard ${ }^{\circledR}$ cotton. J Insect Sci. 2001;1: 13.

Ali M, Luttrell R, Young S III. Susceptibilities of Helicoverpa zea and Heliothis virescens (Lepidoptera: Noctuidae) populations to Cry1Ac insecticidal protein. J Econ Entomol. 2006:99(1):164-75.

Arya SK, Dhar YV, Upadhyay SK, et al. De novo characterization of Phenacoccus solenopsis transcriptome and analysis of gene expression profiling during development and hormone biosynthesis. Sci Rep. 2018;8(1):1-13.

Bakhsh A, Rao AQ, Shahid AA, Husnain T. Spatio temporal expression pattern of an insecticidal gene (cry2A) in transgenic cotton lines. Notulae Scientia Biologicae. 2012:4:115-9.

Bambawale O, Tanwar R, Sharma O, et al. Impact of refugia and integrated pest management on the performance of transgenic (Bacillus thuringiensis) cotton (Gossypium hirsutum). Indian J Agric Sci. 2010;80(8):730-6.

Barkhade UP, Thakare A. Protease mediated resistance mechanism to Cry $1 \mathrm{C}$ and Vip3A in Spodoptera litura. Egypt Acad J Biol Sci: A-Entomol. 2010;3(2):43-50

Bass C, Zimmer CT, Riveron JM, et al. Gene amplification and microsatellite polymorphism underlie a recent insect host shift. Proc Natl Acad Sci. 2013; 110(48):19460-5.

Bernardi O, Bernardi D, Horikoshi RJ, et al. Selection and characterization of resistance to the Vip3Aa20 protein from Bacillus thuringiensis in Spodoptera frugiperda. Pest Manag Sci. 2016;72(9):1794-802.

Brevault T, Heuberger S, Zhang M, et al. Potential shortfall of pyramided transgenic cotton for insect resistance management. Proc Natl Acad Sci. 2013;110(15):5806-11.

Brookes G, Barfoot P. Environmental impacts of genetically modified (GM) crop use 1996-2018: impacts on pesticide use and carbon emissions. GM Crops Food. 2020a;11(4):215-41.

Brookes G, Barfoot P. GM crop technology use 1996-2018: farm income and production impacts. GM Crops Food. 2020b;11(4):242-61.

Calles-Torrez V, Knodel JJ, Boetel MA, et al. Field-evolved resistance of northern and western corn rootworm (Coleoptera: Chrysomelidae) populations to corn hybrids expressing single and pyramided Cry3Bb1 and Cry34/35Ab1 Bt proteins in North Dakota. J Econ Entomol. 2019;112(4):1875-86.

Carey AF, Wang G, Su CY, et al. Odorant reception in the malaria mosquito Anopheles gambiae. Nature. 2010;464(7285):66-71.

Carpenter JE. Peer-reviewed surveys indicate positive impact of commercialized GM crops. Nat Biotechnol. 2010;28(4):319-21.

Carrière Y, Brown ZS, Downes SJ, et al. Governing evolution: a socioecological comparison of resistance management for insecticidal transgenic Bt crops among four countries. Ambio. 2019;49(1):1-16,

Carrière Y, Crickmore N, Tabashnik BE. Optimizing pyramided transgenic Bt crops for sustainable pest management. Nat Biotechnol. 2015;33(2):161.

Carriere Y, Ellers-Kirk C, Hartfield K, et al. Large-scale, spatially-explicit test of the refuge strategy for delaying insecticide resistance. Proc Natl Acad Sci. 2012; 109(3):775-80.

Carrière Y, Fabrick JA, Tabashnik BE. Can pyramids and seed mixtures delay resistance to Bt crops? Trends Biotechnol. 2016;34(4):291-302.

Chakroun M, Banyuls N, Bel Y, et al. Bacterial vegetative insecticidal proteins (Vip) from entomopathogenic bacteria. Microbiol Mol Biol Rev. 2016;80(2):329-50.

Chen C, Buhl E, Xu M, et al. Drosophila lonotropic Receptor 25a mediates circadian clock resetting by temperature. Nature. 2015;527(7579):516-20 https://doi.org/10.1128/MMBR.00060-15.

Chen P, Xiao Q, Zhang J, et al. Occurrence prediction of cotton pests and diseases by bidirectional long short-term memory networks with climate and atmosphere circulation. Comput Electron Agric. 2020;176:105612.

Chen W, Hasegawa DK, Kaur N, et al. The draft genome of whitefly Bemisia tabaci MEAM1, a global crop pest, provides novel insights into virus transmission, host adaptation, and insecticide resistance. BMC Biol. 2016;14(1):110 https:// doi.org/10.1186/s12915-016-0321-y.

Chen WB, Lu GQ, Cheng HM, et al. Transgenic cotton coexpressing Vip3A and Cry $1 \mathrm{Ac}$ has a broad insecticidal spectrum against lepidopteran pests. J Invertebr Pathol. 2017b;149:59-65 https://doi.org/10.1016/j.jip. 2017.08.001.

Chen Y, Li Y, Abidallha EH, et al. Planting density and leaf-square regulation affected square size and number contributing to altered insecticidal protein content in Bt cotton. Field Crop Res. 2017a;205:14-22.

Chen Y, Li Y, Zhou M, et al. Nitrogen (N) application gradually enhances boll development and decreases boll shell insecticidal protein content in $\mathrm{N}$ deficient cotton. Front Plant Sci. 2018;9:51.

Conant GC, Wolfe KH. Turning a hobby into a job: how duplicated genes find new functions. Nat Rev Genet. 2008:9(12):938-50.

Crespo ALB, Alves AP, Wang Y, et al. Survival of corn earworm (Lepidoptera: Noctuidae) on Bt maize and cross-pollinated refuge ears from seed blends. J Econ Entomol. 2015;109(1):288-98.

Cui J, Chen H, Zhao X, et al. Research course of the cotton IPM and its prospect. Cotton Sci. 2007;19(5):385-90

Dohlman E, Johnson J, MacDonald S, et al. The world and united states cotton outlook: US Dep Agric, Agric Outlook Forum; 2019.

Dong H, Li W. Variability of endotoxin expression in Bt transgenic cotton. J Agron Crop Sci. 2007:193:21-9.

Downes S, Mahon R. Evolution, ecology and management of resistance in Helicoverpa spp. to Bt cotton in Australia. J Invertebr Pathol. 2012;110(3):2816 https://doi.org/10.1016/j.jip.2012.04.005.

Downes S, Walsh T, Tay WT. Bt resistance in Australian insect pest species. Curr Opin Insect Sci. 2016;15:78-83.

Flachs A. Transgenic cotton: high hopes and farming reality. Nat Plants. 2017;3(1): $1-2$

Fleming D, Musser F, Reisig D, et al. Effects of transgenic Bacillus thuringiensis cotton on insecticide use, heliothine counts, plant damage, and cotton yield: A meta-analysis, 1996-2015. PLoS One. 2018;13(7):e0200131 https://doi.org/ 10.1371/journal.pone.0200131.

Gahan L, Gould F, Heckel DG. Identification of a gene associated with Bt resistance in Heliothis virescens. Science. 2001;293(5531):857-60.

Gassmann AJ, Petzold-Maxwell JL, Clifton EH, et al. Field-evolved resistance by western corn rootworm to multiple Bacillus thuringiensis toxins in transgenic maize. Proc Natl Acad Sci. 2014;111(14):5141-6.

Gouin A, Bretaudeau A, Nam K, et al. Two genomes of highly polyphagous lepidopteran pests (Spodoptera frugiperda, Noctuidae) with different hostplant ranges. Sci Rep. 2017;7(1):1-12 https://doi.org/10.1038/s41598-01710461-4.

Grimi D, Ocampo F, Martinelli S, Head G, editors. Detection and characterization of Diatraea saccharalis resistant to Cry1A. 105 protein in a population of 
northeast San Luis province in Argentina. Posadas: Congreso Argentino de Entomología; 2015.

Han Q, Wang Z, He Y, et al. Transgenic cotton plants expressing the HaHR3 gene conferred enhanced resistance to Helicoverpa armigera and improved cotton yield. Int J Mol Sci. 2017;18:1874.

Heckel, David G. Learning the ABCs of Bt: $A B C$ transporters and insect resistance to Bacillus thuringiensis provide clues to a crucial step in toxin mode of action. Pesticide Biochemistry \& Physiology. 2012;104(2):103-10.

Hobbs SL, Warkentin TD, DeLong CM. Transgene copy number can be positively or negatively associated with transgene expression. Plant Mol Biol. 1993;21(1):17-26.

Huang F, Andow DA, Buschman LL. Success of the high-dose/refuge resistance management strategy after 15 years of Bt crop use in North America. Entomol Exp et Applicata. 2011;140(1):1-16

Ibrahim AB, Monteiro TR, Cabral GB, Aragão FJ. RNAi-mediated resistance to whitefly (Bemisia tabaci) in genetically engineered lettuce (Lactuca sativa). Transgenic Res. 2017;26:613-24.

ISAAA. Global status of commercialized biotech/GM crops: 2018. Brief No. 54 USA: ISAAA NY; 2018.

Isono K, Morita H. Molecular and cellular designs of insect taste receptor system. Front Cell Neurosci. 2010;4:20.

Jin L, Zhang H, Lu Y, et al. Large-scale test of the natural refuge strategy for delaying insect resistance to transgenic Bt crops. Nat Biotechnol. 2015;33(2):169.

Jurat-Fuentes JL, Karumbaiah L, Jakka SRK, et al. Reduced levels of membranebound alkaline phosphatase are common to lepidopteran strains resistant to Cry toxins from Bacillus thuringiensis. PLoS One. 2011;6(3):e17606 https://doi. org/10.1371/journal.pone.0017606.

Khan AM, Ashfaq M, Khan AA, et al. Evaluation of potential RNA-interferencetarget genes to control cotton mealybug, Phenacoccus solenopsis (Hemiptera: Pseudococcuidae). Insect Sci. 2018a;25:778-86.

Khan MI, Khan AA, Cheema HMN, Khan RSA. Spatio-temporal and intra-plant expression variability of insecticidal gene (Cry1Ac) in upland cotton. Int J Agric Biol. 2018b;20:715-22

Kranthi K, Stone GDJNP. Long-term impacts of Bt cotton in India. Nat Plants. 2020;6(3):188-96.

Kranthi KR, Naidu S, Dhawad C, Tatwawadi A, Mate K, Patil E, Bharose A, Behere G, Wadaskar R, Kranthi S. Temporal and intra-plant variability of Cry1AC expression in Bt-cotton and its influence on the survival of the cotton bollworm, Helicoverpa armigera (Hübner)(Noctuidae: Lepidoptera). Curr Sci. 2009;89(2):291-8.

Li S, Hussain F, Unnithan GC, et al. A long non-coding RNA regulates cadherin transcription and susceptibility to Bt toxin Cry1Ac in pink bollworm, Pectinophora gossypiella. Pestic Biochem Physiol. 2019;158:54-60.

Little NS, Elkins BH, Mullen RM, et al. Differences between two populations of bollworm, Helicoverpa zea (Lepidoptera: Noctuidae), with variable measurements of laboratory susceptibilities to Bt toxins exposed to non-Bt and Bt cottons in large field cages. PLoS One. 2019;14(3):e0212567.

Liu C, Xiao Y, Li X, et al. Cis-mediated down-regulation of a trypsin gene associated with Bt resistance in cotton bollworm. Sci Rep. 2014;4:7219.

Luo S, Naranjo SE, Wu K. Biological control of cotton pests in China. Biol Control. 2014;68:6-14

Luo Z, Dong H, Li W, Ming Z, Zhu Y. Individual and combined effects of salinity and waterlogging on Cry1Ac expression and insecticidal efficacy of Bt cotton. Crop Prot. 2008;27:1485-90.

Majumdar R, Rajasekaran K, JWJFips C. RNA interference (RNAi) as a potential tool for control of mycotoxin contamination in crop plants: concepts and considerations. Front Plant Sci. 2017;8:200.

Maligeppagol M, Asokan R, Krishna $\mathrm{V}$, et al. Transgenic tomato expressing dsRNA of juvenile hormone acid O-methyl transferase gene of Helicoverpa armigera (Lepidoptera: Noctuidae) affects larval growth and its development. J Asia Pac Entomol. 2017;20:559-67.

Malik HJ, Raza A, Amin I, et al. RNAi-mediated mortality of the whitefly through transgenic expression of double-stranded RNA homologous to acetylcholinesterase and ecdysone receptor in tobacco plants. Sci Rep. 2016; 6:38469.

Mao YB, Cai WJ, Wang JW, et al. Silencing a cotton bollworm P450 monooxygenase gene by plant-mediated RNAi impairs larval tolerance of gossypol. Nat Biotechnol. 2007;25(11):1307-13.

Mao YB, Tao XY, Xue XY, et al. Cotton plants expressing CYP6AE14 double-stranded RNA show enhanced resistance to bollworms. Transgenic Res. 2011;20(3):665-73.

Mao YB, Xue XY, Tao XY, et al. Cysteine protease enhances plant-mediated bollworm RNA interference. Plant Mol Biol. 2013;83(1-2):119-29.
Mathew LG, Ponnuraj J, Mallappa B, et al. ABC transporter mis-splicing associated with resistance to Bt toxin Cry2Ab in laboratory-and field-selected pink bollworm. Sci Rep. 2018;8(1):1-15.

Morin S, Biggs RW, Sisterson MS, et al. Three cadherin alleles associated with resistance to Bacillus thuringiensis in pink bollworm. Proc Natl Acad Sci. 2003; 100(9):5004-9.

Naik VC, Kumbhare S, Kranthi S, et al. Field-evolved resistance of pink bollworm, Pectinophora gossypiella (Saunders)(Lepidoptera: Gelechiidae), to transgenic Bacillus thuringiensis (Bt) cotton expressing crystal 1Ac (Cry1Ac) and Cry2Ab in India. Pest Manag Sci. 2018;74(11):2544-54.

Naik VCB, Pusadkar PP, Waghmare ST, et al. Evidence for population expansion of cotton pink bollworm Pectinophora gossypiella (Saunders)(Lepidoptera: Gelechiidae) in India. 2020;10(1):1-11.

Naranjo SE. Impacts of Bt transgenic cotton on integrated pest management. J Agric Food Chem. 2011;59(11):5842-51.

Ni M, Ma W, Wang $X$, et al. Next-generation transgenic cotton: pyramiding RNA and Bt counters insect resistance. Plant Biotechnol J. 2017;15(9):1204-13.

Nicholson SJ, Nickerson ML, Dean M, et al. The genome of Diuraphis noxia, a global aphid pest of small grains. BMC Genomics. 2015;16(1):429.

Niu Y, Yang F, Dangal V, et al. Larval survival and plant injury of Cry $1 F$ susceptible, -resistant, and -heterozygous fall armyworm (Lepidoptera: Noctuidae) on non-Bt and Bt corn containing single or pyramided genes. Crop Prot. 2014;59:22-8.

Pearce SL, Clarke DF, East PD, et al. Genomic innovations, transcriptional plasticity and gene loss underlying the evolution and divergence of two highly polyphagous and invasive Helicoverpa pest species. BMC Biol. 2017;15(1):63.

Pickett BR, Gulzar A, Ferré J, et al. Laboratory selection and characterization of resistance to the Bacillus thuringiensis Vip3Aa toxin in Heliothis virescens (Lepidoptera: Noctuidae). Appl Environ Microbiol. 2017;83(9): e03506-16.

Quan Q, Hu X, Pan B, et al. Draft genome of the cotton aphid Aphis gossypii. Insect Biochem Mol Biol. 2019;105:25-32.

Rana A, Khan SU, Ali S, et al. Effect of temperature on Bt gene expression in candidate cotton lines of Pakistan. American-Eurasian J of Toxicological Sciences. 2015:7(1):26-33.

Raza A, Malik HJ, Shafiq M, et al. RNA interference based approach to down regulate osmoregulators of whitefly (Bemisia tabaci): potential technology for the control of whitefly. PLoS One. 2016;11:e0153883.

Reddy K, Rajam M. Targeting chitinase gene of Helicoverpa armigera by hostinduced RNA interference confers insect resistance in tobacco and tomato. Plant Mol Biol. 2016;90:281-92.

Reisig DD, Huseth AS, Bacheler JS, et al. Long-term empirical and observational evidence of practical Helicoverpa zea resistance to cotton with pyramided Bt toxins. J Econ Entomol. 2018:111(4):1824-33.

Ren M, Zafar MM, Mo H, et al. Fighting against fall armyworm by using multiple genes pyramiding and silencing (MGPS) technology. Sci China Life Sci. 2019; 62(12):1703-6.

Sanahuja G, Banakar R, Twyman RM, et al. Bacillus thuringiensis: a century of research, development and commercial applications. Plant Biotechnol J. 2011;9(3):283-300.

Sánchez-Gracia A, Vieira FG, Almeida FC, et al. Comparative genomics of the major chemosensory gene families in Arthropods. In: eLS: Wiley, Ltd; 2001. https://doi.org/10.1002/9780470015902.a0022848.

Santos-Amaya OF, Rodrigues JV, Souza TC, et al. Resistance to dual-gene Bt maize in Spodoptera frugiperda: selection, inheritance, and cross-resistance to other transgenic events. Sci Rep. 2015;5:18243.

Singh S, Pandher S, Gupta M, et al. Reference gene selection in Phenacoccus solenopsis Tinsley (Hemiptera: Pseudococcidae) and their normalization impact on gene expression in RNAi studies. J Econ Entomol. 2019a;112(1):371-81.

Singh S, Gupta M, Pandher S, et al. Using de novo transcriptome assembly and analysis to study RNAi in Phenacoccus solenopsis Tinsley (Hemiptera: Pseudococcidae). Sci Rep. 2019b;9(1):1-16.

Soberón M, Pardo-López L, López I, et al. Engineering modified Bt toxins to counter insect resistance. Science. 2007;318(5856):1640-2.

Storer NP, Kubiszak ME, King JE, et al. Status of resistance to Bt maize in Spodoptera frugiperda: lessons from Puerto Rico. J Invertebr Pathol. 2012; 110(3):294-300.

Sylvestre-Gonon E, Law S, Schwartz M, et al. Functional, structural and biochemical features of plant serinyl-glutathione transferases. Front Plant Sci. 2019;10:608 
Tabashnik BE, Brévault T, Carrière Y. Insect resistance to Bt crops: lessons from the first billion acres. Nat Biotechnol. 2013;31(6):510.

Tabashnik BE, Carrière Y. Surge in insect resistance to transgenic crops and prospects for sustainability. Nat Biotechnol. 2017;35(10):926.

Tabashnik BE, Carrière Y. Evaluating cross-resistance between vip and cry toxins of Bacillus thuringiensis. J Econ Entomol. 2020;113(2):553-61.

Tabashnik BE, Gassmann AJ, Crowder DW, et al. Insect resistance to Bt crops: evidence versus theory. Nat Biotechnol. 2008;26(2):199-202.

Tabashnik BE, Huang F, Ghimire MN, et al. Efficacy of genetically modified Bt toxins against insects with different genetic mechanisms of resistance. Nat Biotechnol. 2011;29(12):1128

Tabashnik BE, Morin S, Unnithan GC, et al. Sustained susceptibility of pink bollworm to Bt cotton in the United States. GM Crops Food. 2012;3(3):194200.

Tabashnik BE, Mota-Sanchez D, Whalon ME, et al. Defining terms for proactive management of resistance to Bt crops and pesticides. J Econ Entomol. 2014; 107(2):496-507.

Tabashnik BE, Sisterson MS, Ellsworth PC, et al. Suppressing resistance to Bt cotton with sterile insect releases. Nat Biotechnol. 2010;28(12):1304.

Tabashnik BE, Van Rensburg J, Carrière Y. Field-evolved insect resistance to Bt crops: definition, theory, and data. J Econ Entomol. 2009:102(6):2011-25.

Tarazi R, Jimenez JLS, Vaslin MF. Biotechnological solutions for major cotton (Gossypium hirsutum) pathogens and pests. Biotechnol Res Innov. 2019;3(1): $19-26$.

Tassone EE, Zastrow-Hayes G, Mathis J, et al. Sequencing, de novo assembly and annotation of a pink bollworm larval midgut transcriptome. GigaScience. 2016;5(1):s13742 -016-0130-9.

Tay WT, Mahon RJ, Heckel DG, et al. Insect resistance to Bacillus thuringiensis toxin Cry2Ab is conferred by mutations in an ABC transporter subfamily A protein. PLoS Genet. 2015;11(11):e1005534 https://doi.org/10.1371/journal. pgen.1005534.

Teese MG, Campbell PM, Scott C, et al. Gene identification and proteomic analysis of the esterases of the cotton bollworm, Helicoverpa armigera. Insect Biochem Mol Biol. 2010;40(1):1-16.

Tian G, Cheng L, Qi X, et al. Transgenic cotton plants expressing double-stranded RNAs target HMG-CoA reductase (HMGR) gene inhibits the growth, development and survival of cotton bollworms. Int J Biol Sci. 2015;11:1296.

USDA-FAS. Cotton outlook. https://www.fas.usda.gov/commodities/cotton. Accessed 10 Sept 2019.

Veettil PC, Krishna W, MJAJoA Q, et al. Ecosystem impacts of pesticide reductions through Bt cotton adoption. Aust J Agric Resource Econ. 2017;61 (1):115-34.

Wan $P$, Huang $Y, W u ~ H$, et al. Increased frequency of pink bollworm resistance to Bt toxin Cry1Ac in China. PLoS One. 2012;7(1):e29975.

Wan P, Wu K, Huang M, et al. Seasonal pattern of infestation by pink bollworm Pectinophora gossypiella (Saunders) in field plots of Bt transgenic cotton in the Yangtze River valley of China. Crop Prot. 2004;23(5):463-7.

Wan P, Zhang Y, Wu K, et al. Seasonal expression profiles of insecticidal protein and control efficacy against Helicoverpa armigera for Bt cotton in the Yangtze River valley of China. J Econ Entomol. 2005;98(1):195-201.

Wang $H$, Shi Y, Wang L, et al. CYP6AE gene cluster knockout in Helicoverpa armigera reveals role in detoxification of phytochemicals and insecticides. Nat Commun. 2018a;9(1):1-8.

Wang J, Zuo YY, Li LL, et al. Knockout of three aminopeptidase $\mathrm{N}$ genes does not affect susceptibility of Helicoverpa armigera larvae to Bacillus thuringiensis Cry1A and Cry2A toxins. Insect Sci. 2020;27(3):440-8.

Wang L, Ma Y, Wan P, et al. Resistance to Bacillus thuringiensis linked with a cadherin transmembrane mutation affecting cellular trafficking in pink bollworm from China. Insect Biochem Mol Biol. 2018b;94:28-35.

Wang S, Kain W, Wang P. Bacillus thuringiensis Cry1 A toxins exert toxicity by multiple pathways in insects. Insect Biochem Mol Biol. 2018c;102:59-66.

Wang YH, Gao J, Sun MF, et al. Impacts of soil salinity on Bt protein concentration in square of transgenic Bt cotton. PLoS One. 2018;13(11): e0207013 https://doi.org/10.1371/journal.pone.0207013.

Watson G. Comparing RNA interference methods in planarians. 2018. https:// scholarworks.wmich.edu/honors_theses/2984/. Accessed 9 Sept 2019.

Wu C, Chakrabarty S, Jin M, et al. Insect ATP-binding cassette (ABC) transporters: roles in xenobiotic detoxification and Bt insecticidal activity. Int J Mol Sci. 2019:20(11):2829.

Wu KM, Lu YH, Feng HQ, et al. Suppression of cotton bollworm in multiple crops in China in areas with Bt toxin-containing cotton. Science. 2008:321(5896): $1676-8$.
Wu XM, Yang CQ, Mao YB, et al. Targeting insect mitochondrial complex I for plant protection. Plant Biotechnol J. 2016;14(9):1925-35.

Xiao Y, Zhang T, Liu C, et al. Mis-splicing of the ABCC2 gene linked with Bt toxin resistance in Helicoverpa armigera. Sci Rep. 2014;4:6184.

Xie W, Yang X, Chen C, et al. The invasive MED/Q Bemisia tabaci genome: a tale of gene loss and gene gain. BMC Genomics. 2018;19(1):68.

Xu X, Yu L, Wu Y. Disruption of a cadherin gene associated with resistance to Cry1Ac $\delta$-endotoxin of Bacillus thuringiensis in Helicoverpa armigera. Appl Environ Microbiol. 2005;71(2):948-54

Xu Y-L, He P, Zhang L, et al. Large-scale identification of odorant-binding proteins and chemosensory proteins from expressed sequence tags in insects. BMC Genomics. 2009;10(1):632.

Yang F, González JCS, Williams J, et al. Occurrence and ear damage of Helicoverpa zea on transgenic Bacillus thuringiensis maize in the field in Texas, US and its susceptibility to Vip3A protein. Toxins. 2019;11(2):102.

Yang F, Kerns DL, Head G, et al. Susceptibility of Cry 1F-maize resistant, heterozygous, and susceptible Spodoptera frugiperda to Bt proteins used in the transgenic cotton. Crop Prot. 2017a;98:128-35.

Yang F, Morsello S, Head GP, et al. F2 screen, inheritance and cross-resistance of field-derived Vip3A resistance in Spodoptera frugiperda (Lepidoptera: Noctuidae) collected from Louisiana, USA. Pest Manag Sci. 2018;74(8):176978.

Yang L, Lin Z, Fang Q, et al. The genomic and transcriptomic analyses of serine proteases and their homologs in an endoparasitoid, Pteromalus puparum. Dev Comp Immunol. 2017b;77:56-68.

Younis A, Siddique MI, Kim CK, et al. RNA interference (RNAi) induced gene silencing: a promising approach of hi-tech plant breeding. Int J Biol Sci. 2014 10(10):1150.

Yuan C, Wen YJ, Cothren JT, et al. Effects of extreme air temperature and humidity on the insecticidal expression level of Bt cotton. J Integr Agric. 2012;11:1836-44

Zeng Y, Yang YT, Wu QJ, et al. Genome-wide analysis of odorant-binding proteins and chemosensory proteins in the sweet potato whitefly, Bemisia tabaci. Insect Sci. 2019;26(4):620-34.

Zhang H, Tian W, Zhao J, et al. Diverse genetic basis of field-evolved resistance to Bt cotton in cotton bollworm from China. Proc Natl Acad Sci. 2012; 109(26):10275-80.

Zhang S, Cheng H, Gao Y, et al. Mutation of an aminopeptidase $\mathrm{N}$ gene is associated with Helicoverpa armigera resistance to Bacillus thuringiensis Cry1Ac toxin. Insect Biochem Mol Biol. 2009;39(7):421-9.

Zhang X, Rui QZ, Liang PP, et al. Dynamics of Bt cotton Cry1Ac protein content under an alternating high temperature regime and effects on nitrogen metabolism. J Integr Agric. 2018;17:1991-8.

Zhang X, Wang J, Peng S, et al. Effects of soil water deficit on insecticidal protein expression in boll shells of transgenic Bt cotton and the mechanism. Front Plant Sci. 2017:8:2107.

Zhao JZ, Cao J, Collins HL, et al. Concurrent use of transgenic plants expressing a single and two Bacillus thuringiensis genes speeds insect adaptation to pyramided plants. Proc Natl Acad Sci. 2005;102(24):8426-30.
Ready to submit your research? Choose BMC and benefit from:
- fast, convenient online submission
- thorough peer review by experienced researchers in your field
- rapid publication on acceptance
- support for research data, including large and complex data types
- gold Open Access which fosters wider collaboration and increased citations
- maximum visibility for your research: over $100 \mathrm{M}$ website views per year
At BMC, research is always in progress.
Learn more biomedcentral.com/submissions 